\title{
Emancipatiebeleid tussen geleefde droom en onvoltooide daad
}

\author{
Joop Schippers
}

TVGN 20 (2): 141-146

DOI: 10.5117/TVGN2017.2.SCHI

\begin{abstract}
The author also comments on the interview with D'Ancona and Bussemaker. He enumerates the similarities between them: their enthusiasm and their struggles to 'frame' the problem of emancipation in a correct way. Both make a distinction between the substance and the process of emancipation policy, making it all the more surprising, he argues, that so little has been done in the past years to establish new institutions and to generate continuity. Lack of consensus between political parties about the way forward has generated an incremental way of policy making, resulting in a patchwork of regulations, which are often very confusing to the public. Schippers, furthermore, draws attention to the differences between the interviewees in view of the work/ care problem - sharing between partners or stimulating the commercialisation of care work.
\end{abstract}

Keywords: gender equality policies, feminism, politics, state, women's movement

De interviews met beide PvdA-(ex-)bewindspersonen annex emancipatiecoryfeeën tonen een aantal opvallende gelijkenissen, maar ook verschillen. De overeenkomst tussen Hedy d'Ancona en Jet Bussemaker betreffen in de eerste plaats hun bevlogenheid. Daarin zijn zij door de bewindspersonen die tussen hen in de emancipatiescepter zwaaiden onovertroffen, ook al hebben voor het emancipatiebeleid verantwoordelijke bewindspersonen als Jan de Koning (CDA) en vooral Ad Melkert ( $\operatorname{PvdA}$ ) ook de nodige resultaten op hun conto staan.

Een tweede punt van overeenkomst betreft de worsteling die de emancipatieportefeuille voor beide bewindsvrouwen met zich mee bracht. Niet alleen om greep te krijgen op de materie zelf, maar ook om het emancipa- 
tievraagstuk op de juiste wijze te 'framen', en vooral ook om een verkeerde framing tegen te gaan. Die 'foutieve' framing is niet alleen kwestie van onbegrip bij belanghebbenden of de media, maar soms ook een bewuste actie van degenen die het liefst alles bij het oude laten. Dat ondervonden niet alleen de geïnterviewde bewindspersonen, maar bijvoorbeeld ook D66-staatssecretaris Annelies Verstand toen zij rond de eeuwwisseling aangaf het zogeheten combinatiescenario waarin een 32 -urige werkweek voor zowel vrouwen als mannen de nieuwe norm zou worden als uitgangspunt voor het beleid te willen omarmen (Sociaal-Economische Raad, 2000). In Nederland krijgen politici die maatregelen voorstellen welke veranderingen op emancipatieterrein bepleiten al snel het verwijt naar het hoofd geslingerd een inbreuk te maken op de keuzevrijheid van de zelfstandige burger. Dat die burger - en zeker als zij een vrouw is - de facto vaak nauwelijks keuzevrijheid heeft, omdat de status quo van de traditionele keuzes stevig institutioneel verankerd is, blijft veelal onbesproken. Overheidsbeleid is immers nooit neutraal; altijd liggen veronderstellingen over gewenst c.q. 'normaal' gedrag ten grondslag aan regels, het aanbod van voorzieningen of het ontbreken daarvan. Alleen vanwege het feit dat die veronderstellingen veelal impliciet blijven, lijkt het vaak net alsof het beleid neutraal is, maar dat is slechts schijn.

Een derde punt van overeenkomst tussen de uitspraken van Hedy d'Ancona en Jet Bussemaker betreft het onderscheid dat zij maken tussen de inhoud van het emancipatiebeleid en het proces. Hedy d'Ancona verwijst een aantal keren expliciet naar onderdelen van de 'national machinery', zoals de EmancipatieKommissie (later: Emancipatieraad) en de Visitatiecommissie Emancipatie (VCE), die halverwege het eerste decennium van deze eeuw onder leiding van Tineke Lodders (CDA) de stand van het emancipatiebeleid nog eens onder de loep nam - en tot de conclusie kwam dat het emancipatiebeleid anno 2007 bij lange na niet op orde was) (Visitatiecommissie Emancipatie, 2007). Jet Bussemaker benadrukt tot tweemaal toe dat het thema emancipatie onderhoud vraagt en nooit af is. Velen die deze stelling van harte onderschrijven, zullen zich dan toch afvragen waarom in de achterliggende kabinetsperiode geen initiatieven zijn genomen om onderhoud en monitoring van het emancipatieproces (opnieuw) een structureler karakter te geven. Institutionalisering van aandacht voor (de kwaliteit van) het emancipatiebeleid kan voorkomen dat er vooral stappen voorwaarts worden gezet als er een bewindspersoon aantreedt bij wie emancipatie daadwerkelijk tussen de oren zit. Het verleden heeft laten zien dat gebrek aan expliciete aandacht, ook voor wat al bereikt is of lijkt, er toe leidt dat de bestaande verworvenheden zo weer wegspoe- 
len. Daarom hebben we een Voedsel- en Warenautoriteit die de voedselkwaliteit monitort, de Belastinginspectie voor de belastinginning, de Onderwijsinspectie, de Inspectie voor de Gezondheidszorg en zo verder, en zo zou het ten aanzien van de stand van emancipatie en (de kwaliteit van) het emancipatiebeleid in Nederland ook moeten gaan. Er zijn - zoals Jet Bussemaker terecht aangeeft - telkens weer nieuwe bedreigingen en uitdagingen voor die emancipatie, en het feit dat en de wijze waarop deze tegemoet worden getreden zouden geen vrijblijvende kwestie moeten zijn.

Qua inhoud tonen de vraagstukken waarmee beide bewindspersonen zich bezig moesten houden op het eerste gezicht wel grote verschillen. Voor een deel weerspiegelen deze het feit dat het nog altijd niet volle emancipatieglas inmiddels toch aanzienlijk beter gevuld is dan in de jaren '8o van de vorige eeuw. Niet alleen zijn allerlei rechten waar vrouwen een halve eeuw geleden nog voor streden wettelijk verankerd, de grootste stap voorwaarts op emancipatieterrein heeft Nederland ongetwijfeld gezet met de enorme en succesvolle participatie van vrouwen in het onderwijs. Deze vorm van verheffing straalt niet alleen uit naar allerlei verschillende domeinen van het leven, maar heeft ook zijn effect op volgende generaties. Natuurlijk, er is nog altijd seksesegregatie in het onderwijs en op de arbeidsmarkt, en op diezelfde arbeidsmarkt werken vrouwen nog te vaak minder uren dan mannen en is er nog altijd sprake van een loonkloof het glas is ook nog niet vol, maar de emancipatie in Nederland heeft niet stilgestaan.

Wie scherper kijkt en tussen de regels van de interviews met Hedy d'Ancona en Jet Bussemaker doorleest, kan echter ook gemakkelijk tot de conclusie komen dat er structureel niet zoveel is veranderd en dat beide bewindspersonen de facto tegen dezelfde problemen oplopen. Mannen en netwerken van mannen hebben nog steeds de macht en mannelijk gedrag is nog steeds de norm. Natuurlijk gaat het wel allemaal 'op zijn Hollands', dus in een - in internationaal-vergelijkend perspectief - relatief feminiene samenleving, en zonder al te veel scherpe randjes. Dat is immers de specialiteit van het poldermodel: het wegslijpen van scherpe randjes en wegmasseren van al te grote tegenstellingen. Vanuit dat perspectief zou je ook kunnen zeggen dat de emancipatie in Nederland op een effectieve manier is ingekapseld en geabsorbeerd. Vrouwen doen mee, zonder dat er wezenlijk iets in de samenleving is veranderd en zonder dat de echte, mannelijke machthebbers de touwtjes uit handen hebben gegeven. Bovendien lijkt op een als mopperende minderheid weggezette kleine groep na - vrijwel iedereen vrede te hebben met deze 'gedoogconstructie'. Van een strijdbare oppositie of voorhoede lijkt nu veel minder sprake dan in 'de tijd van' Hedy 
d'Ancona, ook al geeft bijvoorbeeld het Sociaal en Cultureel Planbureau regelmatig signalen af dat het vrouwen in de Nederlandse samenleving van na de crisis niet altijd even goed gaat (Portegijs \& Van den Brakel, 2016).

In die zin weerspiegelen de interviews met Jet Bussemaker en Hedy d'Ancona tot op zekere hoogte ook de tijd waarin zij aan het roer staan/ stonden, al kan bij Jet Bussemaker ook meespelen dat zij op het moment dat het interview werd afgenomen ook nog daadwerkelijk politieke verantwoordelijkheid droeg in een coalitiekabinet. Hedy d'Ancona stelt ook nu nog de structureel ongelijke arbeidsdeling (van betaald werk en onbetaalde zorgtaken) ter discussie, terwijl de opmerkingen van Jet Bussemaker - over noodzakelijke aanpassingen in de cultuur, ontwikkelingen van de markt voor persoonlijke dienstverlening en het samen met werkgeversvoorzitter Hans de Boer optrekken om de positie van vrouwen in Raden van Bestuur en Raden van Commissarissen te versterken - toch vooral past bij het verder perfectioneren van het poldermodel der emancipatie.

Misschien is die tweede aanpak ook wel realistischer in het licht van de eerder geconstateerde vrijblijvendheid en het gebrek aan consensus rond het emancipatiebeleid dat daaraan ten grondslag ligt. Tussen de grote politieke stromingen is nooit wezenlijke overeenstemming ontstaan over de grondtoon en de koers van het emancipatiebeleid. Vanuit de jaren ' 50 domineerde het gezinsdenken (met de man als hoofd van het gezin) de opstelling van de christendemocratie en het traditionele deel van de sociaaldemocratie. In de jaren ' 90 kantelden de politieke opvattingen en vonden sociaaldemocraten en liberalen elkaar op het gelijkheidsideaal. De verschillen in nadruk op formele versus materiële gelijkheid en vooral het vertrouwen op c.q. gebrek aan vertrouwen in de markt en eigen keuzes van individuen bij respectievelijk liberalen en sociaaldemocraten leidden er echter toe dat ook na deze kanteling van een beleidsmatig relevante consensus geen sprake was (en is) (Peters, 2015). Alleen rond de kinderopvang zijn - juist op basis van overeenstemming tussen VVD en PvdA - zowel in de jaren '9o als bijvoorbeeld bij de motie Van Aartsen/Bos over de buitenschoolse opvang, forse stappen voorwaarts gezet. Andere belangrijke keuzes, zoals die tussen het combinatiemodel en het uitbestedingsmodel eind jaren '9o, zijn echter verzand bij gebrek aan consensus en eenduidige opvattingen over waar het met de emancipatie in Nederland naartoe zou moeten. Met dat gebrek aan consensus in het achterhoofd toont Jet Bussemaker zich wellicht een waardige telg van Joop den Uyl toen hij constateerde dat de smalle marges van democratische politiek beleidsmakers soms betrekkelijk weinig manoeuvreerruimte bieden. Het incrementele emancipatiebeleid dat het gevolg was heeft over de jaren heen wel geleid 
tot een bonte lappendeken van weinig consistente maatregelen en voorzieningen die de burgers $(\mathrm{v} / \mathrm{m})$ weinig zekerheid bieden over hoe te handelen.

Twee opmerkingen uit de interviews verdienen ten slotte nog de aandacht. De eerste betreft de discrepantie tussen het positieve beeld dat het buitenland' van de stand van zaken rondom emancipatie in Nederland heeft en de vaak armzalige werkelijkheid. Niet alleen bewindspersonen worden daarmee geconfronteerd. Ook als wetenschapper beland je regelmatig in de positie dat je moet uitleggen dat het in theorie en op papier in Nederland allemaal keurig is geregeld, maar dat de praktijk daar nogal van afwijkt. Ligt dat aan de (grote) schrijfvaardigheid van onze ambtenaren? Of zien we ook hier de werking van het poldermodel dat de scherpe kantjes van het emancipatievraagstuk wegslijpt, zodat ook rondom de genderverhoudingen in Nederland alles koek en ei en pais en vree lijkt? Als onderzoek dan toont dat er ondanks wetgeving nog altijd frequent sprake is van zwangerschapsdiscriminatie op de arbeidsmarkt of van gênant lage aantallen vrouwen in Raden van Bestuur slaat er niemand met de vuist op tafel, klimt er niemand op de barricaden, maar wordt nader onderzoek ingesteld of mag een stuurgroep over oplossingen nadenken. Alsof we die niet al zouden kennen.

De laatste intrigerende opmerking uit het interview komt van Jet Bussemaker en betreft ook haar laatste opmerking: 'emancipatie is niet alleen het probleem, maar het is vaak ook een oplossing'. Vooral onderzoekers op het terrein van genderstudies zouden zich door zo een uitspraak uitgedaagd moeten voelen. Immers, voor welke maatschappelijke problemen van de komende jaren vormt nu juist emancipatie een oplossing? En wat bedoelt de minister hier dan met emancipatie? Betere condities (een minder vrouwonvriendelijke omgeving) bieden aan vrouwen kan inderdaad wellicht helpen hen voor technische beroepen te winnen of te behouden. Het uitgebreider testen van medicijnen op vrouwelijke proefpersonen kan inderdaad leiden tot effectievere gezondheidszorg. Ook eten vrouwen minder vlees en maken ze meer kilometers op de fiets. Moet hun gedrag wellicht als voorbeeld gelden bij de aanpak van het klimaatprobleem? En misschien kunnen reeds massaal in deeltijd werkende vrouwen een voorbeeld vormen als de robotisering op termijn noodzaakt tot herverdeling van arbeid? Of is een meer feminiene ook een tolerantere samenleving? Je kunt je er van alles bij voorstellen, maar misschien is het toch verstandiger dat de redactie van dit tijdschrift Jet Bussemaker na ommekomst van haar Haagse periode vraagt haar intrigerende stelling zelf een keer in een artikel uit te werken. Ongetwijfeld ben ik niet de enige lezer die daar naar uitziet. 


\section{Bibliografie}

Peters, K. (2015). Een doodgewoon kabinet. Acht jaar Paars, 1994-2002. Amsterdam: Boom.

Portegijs, W., \& van den Brakel, M. (Red.) (2016). Emancipatiemonitor 2016. Den Haag: Sociaal en Cultureel Planbureau.

Sociaal-Economische Raad (2000). Meerjarennota emancipatiebeleid oo/og. Den Haag: SociaalEconomische Raad. Beschikbaar op https://www.ser.nl/nl/publicaties/adviezen/2000-2009/ 2000/b18737.aspx

Visitatiecommissie Emancipatiebeleid (2007). Een beetje beter is niet goed genoeg. Emancipatiebeleid en gender mainstreaming bij de rijksoverheid (Eindrapportage Visitaties 2005-2006 No. VCE-07-15). Beschikbaar op https://zoek.officielebekendmakingen.nl/kst-30420-27-b1

\section{Over de auteur}

Joop Schippers is Hoogleraar Arbeidseconomie, Universiteit Utrecht en voormalig lid van de Emancipatieraad, de Tijdelijke Expertisecommissie Emancipatie in het Nieuwe Adviesstelsel (TECENA) en de Visitatiecommissie Emancipatie, lid van de Monitorcommissie Talent naar de Top. 